\title{
Metody geofizyki otworowej i ich wykorzystanie w projektowaniu i przygotowaniu technologii zabiegów hydraulicznego szczelinowania
}

\begin{abstract}
Geofizyczne profilowania otworowe, w szczególności profilowania elektrometryczne, jądrowe, geochemiczne, nuklearnego rezonansu magnetycznego oraz akustyczne, są powszechnie wykonywanymi pomiarami w odwiertach zlokalizowanych na złożach węglowodorów. Na podstawie profilowań możliwe jest wyznaczenie m.in. współczynnika porowatości, współczynnika nasycenia, określenie litologii ośrodka skalnego, właściwości mechanicznych skał oraz rozkładu naprężeń w złożu. Powyższe parametry wpływają na geometrię szczeliny oraz na parametry zabiegowe: ciśnienie i wydajność tłoczenia, rodzaj użytego płynu zabiegowego oraz podsadzki. Artykuł przedstawia metodologię najważniejszych profilowań geofizyki otworowej i pokazuje, w jaki sposób informacje o parametrach geologicznych i złożowych, pozyskiwane za ich pomocą, wpływają na proces projektowania i przygotowania zabiegu hydraulicznego szczelinowania.
\end{abstract}

Słowa kluczowe: geofizyka otworowa, hydrauliczne szczelinowanie, ocena formacji skalnej, parametry geologiczne.

\section{Well logging methods and their application in the design and preparation of hydraulic fracturing treatment}

\begin{abstract}
Geophysical well measurements, in particular electric, nuclear (including geochemical), magnetic resonance and acoustic logs are commonly performed in wells located on hydrocarbons reservoirs. Information gathered thanks to these logs enables to determine porosity and saturation factors, determine lithology, rock mechanical properties, and stress distribution. These parameters affect the geometry of the fracture and treatment parameters: pressures, fluid delivery rates, amount and type of fluid and proppant. The article describes the basic methodology of well logs and shows how information about geological and reservoir parameters obtained by well logging, can affect the process of designing and preparing hydraulic fracturing treatment.
\end{abstract}

Key words: well logging, hydraulic fracturing, reservoir evaluation, geological parameters.

\section{Wprowadzenie}

Hydrauliczne szczelinowanie jest zabiegiem stymulacyjnym znanym od lat 40. XX wieku. Powszechnie wykonuje się je w drobnoziarnistych skałach macierzysto-zbiornikowych ropy i gazu ziemnego, o bardzo małej przepuszczalności, w celu zwiększenia wydajności produkcji $[13,17]$. Hydrauliczne szczelinowanie polega na zatłoczeniu płynu szczelinującego z materiałem podsadzkowym w caliznę skalną pod ciśnieniem wystarczającym do jej rozerwania i wytworzenia szczeliny. Zabieg ten wykonywany w złożu konwencjonalnym ma na celu utworzenie szczeliny w strefie przyodwiertowej, w której doszło do uszkodzenia przepuszczalności ośrodka skalnego $\mathrm{w}$ wyniku różnego rodzaju prac na odwiercie (wiertniczych, cementacji itp.). Zabieg hydraulicznego szczelinowania w złożu niekonwencjonalnym (np. w złożu gazu ziemnego w formacji łupkowej) prowadzi do utworzenia rozległej sieci szczelin, obejmującej swym zasięgiem dużą część złoża. W wyniku tego procesu węglowodory wypełniające złoże mogą przedostać się do otworu wiertniczego. Innymi słowy, po wykonaniu zabiegu nie powiększa się przepuszczalność matrycy skalnej, 
rośnie natomiast powierzchnia kontaktu złoża z odwiertem $[3,9,10,11,16]$.

Przed przystąpieniem do projektowania i wykonania zabiegu hydraulicznego szczelinowania niezbędna jest ocena formacji skalnej, na podstawie której dobiera się technologię zabiegową (ciśnienia i wydajność tłoczenia, rodzaj płynu, podsadzki itd.), która byłaby najkorzystniejsza w danym przypadku. Najważniejszy czynnik determinujący wykonanie hydraulicznego szczelinowania to niski przypływ mediów do odwiertu. Przypływ ten jest związany bezpośrednio lub pośrednio z szeregiem parametrów charakteryzujących skałę zbiornikową, skały ją otaczające oraz uzależniony jest od ich położenia i wzajemnych relacji. Parametrami ośrodka, których znajomość jest niezbędna dla zaprojektowania skutecznego zabiegu szczelinowania, są:

- współczynnik porowatości,

- współczynnik przepuszczalności,

- litologiczny opis skał,

- skład mineralny (geochemia),

- nasycenie wodą i węglowodorami,

- właściwości mechaniczne skał,
- naprężenia w formacji złożowej i w formacjach otaczających.

Informacje o powyższych parametrach można pozyskać przy użyciu metodyki geofizyki otworowej oraz w wyniku badań laboratoryjnych na rdzeniach wiertniczych. Badania laboratoryjne są mniej kosztowne i czasochłonne, jednak ich wyniki odzwierciedlają parametry jedynie niewielkiej części badanego złoża, z której została pobrana próbka rdzeniowa. Profilowania geofizyki otworowej dostarczają natomiast danych ciągłych, na całym interesującym interwale głębokościowym, w warunkach in situ (w ciśnieniu i temperaturze złożowej), które mogą być trudne do odwzorowania w laboratorium.

Mnogość rodzajów nowoczesnych profilowań geofizycznych i ciągły rozwój aparatury pomiarowej pozwalają w coraz bardziej dokładny sposób opisywać warunki geologiczno-złożowe w górotworze. $\mathrm{W}$ artykule autor prezentuje rolę informacji, uzyskanej drogą najważniejszych i przez to najczęściej wykonywanych profilowań geofizycznych, w procesie projektowania i przygotowania technologii zabiegów hydraulicznego szczelinowania.

\section{Profilowania geofizyki otworowej}

Otworowe profilowania geofizyczne są zespołem czynności geofizycznych wykonywanych w otworach wiertniczych w celu rejestracji zmian parametrów charakteryzujących ośrodek skalny wzdłuż otworu wiertniczego. Profilowania wykonuje się w odwiertach pionowych, bosych (niezarurowanych) oraz zarurowanych przy użyciu sond geofizycznych zapuszczanych na kablu. Sondy łączy się w zestawy pomiarowe dobierane w zależności od informacji, którą chce się uzyskać (np. tradycyjny zestaw pomiarowy Quad Combo zawiera sondy do badań oporności, gęstości objętościowej, porowatości neutronowej, naturalnej promieniotwórczości i analiz akustycznych) [19].
Istnieją również profilowania geofizyczne wykonywane bezpośrednio podczas wiercenia otworu nazywane w skrócie LWD (Logging While Drilling). W takim przypadku urządzenie pomiarowe montowane jest w końcowej części przewodu wiertniczego. Profilowania takie mogą być wykonywane zarówno w odcinkach pionowych otworów jak i w odcinkach kierunkowych lub horyzontalnych. Profilowania LWD mają obecnie zbliżoną dokładność pomiarową do profilowań z użyciem klasycznej sondy na kablu. Dodatkowo za ich pomocą możliwe jest sterowanie kierunkiem wiercenia tak, aby jego trajektoria była na bieżąco dostosowywana do aktualnej sytuacji geologicznej (Geosteering) [6,12,19].

\section{Profilowania elektrometryczne}

Otworowe pomiary elektrometryczne wykorzystują zdolność ośrodka skalnego do stawiania oporu przepływającemu prądowi elektrycznemu. Mierzonym parametrem skały jest elektryczna oporność pozorna. Minerały budujące szkielet skalny mają zazwyczaj dużą oporność właściwą, natomiast w przypadku metali rodzimych, niektórych tlenków i siarczków jest ona bardzo niska. Występowanie minerałów ilastych w skale powoduje spadek jej oporności właściwej, czego przyczyną jest zjawisko adsorpcji jonów z wody złożowej oraz ich ruchliwość w przestrzeni porowej [7].
Bardzo duży wpływ na oporność skały ma oporność mediów złożowych wypełniających przestrzeń porową, ich temperatura oraz odległość mierzonego obszaru od otworu wiertniczego. Im niższa mineralizacja wody złożowej, tym wyższa oporność właściwa roztworu. Natomiast im wyższa temperatura, tym oporność właściwa wody złożowej jest niższa. W strefie przemytej oraz filtracji proces wnikania płuczki do skały nasączonej wodą złożową prowadzi do zmiany oporności tych stref w porównaniu ze stanem naturalnym. Ich oporność jest wtedy zależna od relacji oporności płuczki i mediów złożowych. Wraz ze wzrostem ilości 
węglowodorów w skale rośnie oporność skały (węglowodory są nieprzewodzące) $[7,19]$.

Pomiary elektrometryczne prowadzi się przy użyciu sond wyposażonych w elektrody prądowe oraz elektrody pomiarowe. W klasycznych profilowaniach oporności potencjałowych POp (Normal) i gradientowych POg (Lateral) przez elektrodę prądową przepływa prąd o niewielkiej częstotliwości i rozchodzi się we wszystkich kierunkach wewnątrz otworu wiertniczego wypełnionego płuczką. Kierunek rozchodzenia się prądu jest zależny od oporności płuczki, mediów złożowych oraz oporności warstwy i formacji otaczających. Elektrody pomiarowe mierzą różnice potencjałów $\Delta V$, które - ze względu na wpływ otworu i stref go otaczających - są wartościami pozornymi. W sterowanych profilowaniach oporności POst (Laterolog) wykorzystuje się elektrody ogniskujące, kierujące sygnał dokładnie w część ośrodka podlegającą badaniu (rysunek 1). Sondy te charakteryzują się większą rozdzielczością pionową pomiaru, a wyniki pomiarów przeprowadzonych za ich pomocą są w mniejszym stopniu obarczone wpływem otworu i stref otaczających. Gdy oporność ośrodka jest niska, można stosować sondy indukcyjne dające przy określaniu rzeczywistej oporności takich ośrodków lepsze wyniki niż laterologi. Do badania oporności osadu ilastego lub oporności w strefie przemytej mogą być stosowane sondy do mikroprofilowań. Ich sposób działania jest analogiczny do pracy sond potencjałowych, gradientowych lub sterowanych, jednak ich zasięg jest znacznie mniejszy. Do oddzielenia horyzontów nasyconych węglowodorami od horyzontów wodonośnych stosuje się profilowania dielektryczne (np. sonda mikrofalowa Schlumberger

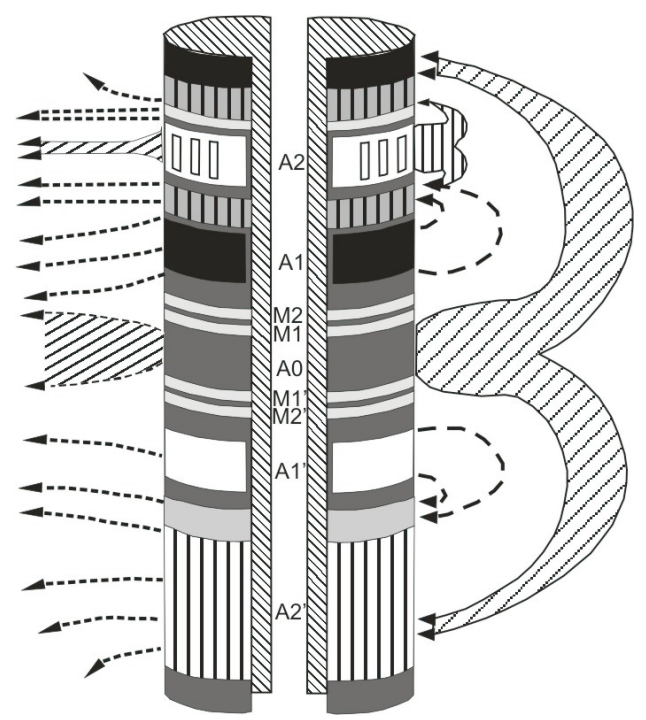

Rys. 1. Schemat ideowy podwójnego laterologu połączonego $\mathrm{z}$ urządzeniem do obrazowania ściany otworu (w górnej części sondy): A0 - elektroda prądowa centralna; A1, A2, A1', A2' - elektrody ogniskujące; M1, M2, M1', M2' - elektrody pomiarowe [5]
EPT). Możliwe jest również badanie ścianek otworu wiertniczego (Electric Imaging) z wykorzystaniem sondy do elektrycznego obrazowania (Schlumberger ARI) [7].

Dzięki pomiarom elektrometrycznym możliwe jest wyznaczenie współczynnika porowatości $\Phi$ oraz współczynnika nasycenia $S$.

Przyjmując, że oporność rzeczywista szkieletu skalnego jest nieskończona w porównaniu z opornością rzeczywistą płynów, można stwierdzić, że oporność skały jest odwrotnie proporcjonalna do porowatości. Zakładając, że w przestrzeni porowej ośrodka skalnego nie występują węglowodory $\left(S_{w}=1\right)$, można obliczyć współczynnik porowatości całkowitej (będący parametrem bezwymiarowym), korzystając ze wzoru [5]:

$$
\Phi=\left[\frac{a R_{w}}{R_{0}}\right]^{1 / m}
$$

gdzie:

$\Phi$ - współczynnik porowatości całkowitej [-],

$R_{w}$ - oporność solanki $[\Omega \mathrm{m}]$,

$R_{0}$ - oporność formacji nasyconej w stu procentach solanką

$[\Omega \mathrm{m}]$,

$a, m$ - stałe zależne od rodzaju skały.

Znajomość współczynnika porowatości jest niezwykle ważna podczas projektowania zabiegu szczelinowania. Duża porowatość skały wymusza stosowanie płynów zabiegowych o większej lepkości oraz dużej ilości podsadzki tak, aby jej ziarna dokładnie wypełniły powstałe w trakcie zabiegu szczeliny. Do transportu większej ilości podsadzki konieczna jest większa ilość płynu zabiegowego. W przypadku szczelinowania w skałach łupkowych, szczególnie płynami o niskiej lepkości typu Slickwater (woda z dodatkiem polimeru syntetycznego lub naturalnego), niezbędne jest stosowanie dużych wydajności tłoczenia i dużych objętości cieczy, co zwiększa ogólny koszt zabiegu. W niektórych sytuacjach stosuje się także zabiegi hybrydowe $\mathrm{z}$ wykorzystaniem naprzemiennie płynów Slickwater oraz bardziej lepkich żelów, ułatwiających transport podsadzki.

Skały o dużej porowatości ułatwiają ucieczkę płynu szczelinującego ze szczeliny w warstwy otaczające (leakoff), przez co również zwiększa się zużycie płynu podczas zabiegu.

Współczynnik porowatości $\Phi$, wraz z współczynnikiem przepuszczalności $k$ (wyznaczanym metodami laboratoryjnymi na rdzeniach wiertniczych, na podstawie korelacji ze współczynnikiem porowatości i nasycenia lub podczas testów formacji złożowej), pozwala na odpowiednie dobranie ciśnienia tłoczenia podczas zabiegu. Wraz ze spadkiem porowatości i przepuszczalności skała wykazuje zazwyczaj większą odporność na rozrywanie, przez co rośnie ciśnienie 
potrzebne do utworzenia w niej szczeliny. Wzrasta również rozmiar samych szczelin.

W zabiegach w skałach o niskiej przepuszczalności stosuje się ciecze szczelinujące typu Slickwater, roztwory polimerów liniowych lub piany. Wraz ze zwiększaniem się przepuszczalności używa się płynów bardziej lepkich: pian lub sieciowanych żeli polimerowych. W przypadku skał o dużej przepuszczalności wykonuje się zabiegi typu Frac pac, czyli szczelinowanie wraz z wykonaniem obsybki [4].

Niska przepuszczalność determinuje również użycie większej ilości podsadzki, jednak o mniejszej granulacji.

Macierzysto-zbiornikowe skały łupkowe są formacjami, w których w niewielkich ilościach występują minerały dobrze przewodzące. Można zatem założyć, że przewodnictwo w tych skałach związane jest z solanką wypełniającą przestrzeń porową. Ponieważ oporność pozorna mierzona jest zarówno w strefie przemytej, jak i strefie niezmienionej, współczynnik nasycenia wodą może być obliczany za pomocą wzoru podanego w pracy [5]. Jest to metoda uproszczona, zakładająca ścisłą zależność pomiędzy nasyceniem strefy przemytej i niezmienionej.

$$
S_{w}=\left(\frac{R_{x 0} / R_{t}}{R_{m f} / R_{w}}\right)^{\alpha}
$$

gdzie:

$S_{w}$ - współczynnik nasycenia wodą,

$R_{m f}$ - znana oporność filtratu płuczki [ $\left.\Omega \mathrm{m}\right]$,

$R_{t}$ - oporność rzeczywista ośrodka skalnego (bez wpływu otworu na pomiar) $[\Omega \mathrm{m}]$,
$R_{w}$ - oporność solanki (uzyskiwana z katalogów lub z pomiarów metodą potencjałów naturalnych) [ $\Omega \mathrm{m}]$,

$R_{x 0}$ - oporność ośrodka w strefie przemytej $[\Omega \mathrm{m}]$,

$\alpha$ - stała wynosząca zazwyczaj $5 / 8$.

Wraz z parametrami litologicznymi oraz geochemicznymi współczynnik nasycenia umożliwia wyznaczenie miejsca wykonania perforacji w otworze, oszacowanie optymalnej długości perforowanego odcinka, a wraz z informacjami o właściwościach mechanicznych skały pozwala zaprojektować oczekiwaną w danym przypadku geometrię szczeliny.

W zależności od nasycenia zmienia się również skład płynu szczelinującego, który musi być kompatybilny z mediami złożowymi. Jeżeli przestrzeń porowa wypełniona jest ropą, odznaczającą się nieściśliwością, stosuje się dodatki zapobiegające powstawaniu emulsji ropno-wodnych (antyemulgatory). Gdy w porach dominuje gaz, który łatwo się spręża, używa się cieczy o większej lepkości i jednocześnie zmniejsza się wydajność tłoczenia oraz ilość zatłaczanego płynu.

Pomiary elektrometryczne POst, zwłaszcza w wersji LWD, pozwalają na badanie orientacji szczelin naturalnych w skałach, co również przyczynia się do dokładniejszego wyznaczenia miejsca perforacji w otworze. Wielokierunkowe laterologi wysokiej rozdzielczości mogą także dostarczać danych pomocnych w oszacowaniu, czy odwiert znajduje się w najbardziej perspektywicznej części złoża (sweet spot), oraz w określeniu stopnia deformacji ścianek otworu, a tym samym - uzyskaniu informacji o polu naprężeń w górotworze [14].

\section{Profilowania jądrowe}

Pomiary jądrowe są podstawowymi pomiarami geofizyki otworowej wykonywanymi podczas prac geofizycznych w odwiertach poszukiwawczych gazu ziemnego lub ropy naftowej. W metodyce profilowań jądrowych wykorzystuje się zjawisko emisji cząstek lub promieniowania przez izotopy promieniotwórcze wchodzące w skład skał ośrodka (profilowania promieniotwórczości naturalnej, metody pasywne) lub przez sztuczne źródła promieniowania (np. profilowania gamma-gamma, metody aktywne). Wykorzystuje się trzy typy oddziaływań promieniowania gamma z materią: absorbcję fotoelektryczną, zjawisko Comptona oraz zjawisko tworzenia par [18].

Do profilowań jądrowych stosuje się sondy wyposażone w liczniki scyntylacyjne, w których wykorzystywane są najczęściej monokryształy jodku sodu aktywowanego talem lub liczniki półprzewodnikowe $[6,18]$.

W profilowaniach promieniotwórczości naturalnej PG (Gamma Log) mierzy się promieniotwórczość trzech głównych grup pierwiastków: rodziny uranu, toru oraz potasu. Istotną informacją z punktu widzenia poszukiwań i charakterystyki niekonwencjonalnych zasobów węglowodorów, uzyskiwaną na podstawie profilowań PG, jest zawartość minerałów ilastych w skale (tzw. zailenie). Wyznaczenie zailenia jedynie przy użyciu metody PG jest trudne, gdyż - wykonując ten rodzaj badania - nie można stwierdzić, od którego pierwiastka promieniotwórczego promieniowanie pochodzi, co prowadzi do dużych niedokładności w pomiarach. Dlatego w otworach poszukiwawczych wykonuje się pomiary spektrometryczne gamma sPG (Spectral Gamma Log) pozwalające na dokładne określenie koncentracji pierwiastków promieniotwórczych w badanym ośrodku skalnym, dzięki możliwości rejestracji widm promieniowania gamma poszczególnych izotopów [12]. Metoda sPG pozwala również na wykrycie skał o zwiększonej zawartości substancji organicznej, w których występują koncentracje uranu (skał, w których mogły generować się węglowodory). 
W metodzie gamma-gamma (PGG) stosuje się źródło umieszczone w sondzie poniżej detektora (najczęściej ${ }^{137} \mathrm{Cs}$ ). Mierzy się skutki oddziaływania promieniowania ze skałą (promieniowanie rozproszone). Na podstawie zjawiska fotoelektrycznego, którego wpływ rośnie ze spadkiem energii rozpraszanych kwantów, można określić ekwiwalentną liczbę atomową $Z_{e q}$, ściśle powiązaną ze składem chemicznym skały, a więc $z$ jej litologią. Obecnie w poszukiwawczych otworach naftowych wykonuje się profilowania gamma-gamma gęstościowe (PGGg, Density Log) oraz profilowania litologiczno-gęstościowe (Litho Density Log), które oprócz informacji litologicznej, dzięki zastosowaniu sondy spektrometrycznej, pozwalają na identyfikację niektórych minerałów [18].

W metodyce profilowań neutronowych PN (Neutron Log, Porosity Log) wykorzystuje się zjawisko propagacji neutronów szybkich (o energii kilku MeV i szybkości około $3000 \mathrm{~cm} / \mu \mathrm{s}$ ), ze źródła wykorzystującego izotopy Ameryku i Berylu przez ośrodek skalny (profilowania neutronowe izotopowe).

Wykorzystuje się także źródła impulsowe zwane generatorami neutronów, emitujące neutrony o energii około $14,1 \mathrm{MeV}$ (profilowania neutronowe akceleratorowe). Ten rodzaj profilowań neutronowych umożliwia uzyskanie największego spektrum informacji o badanym ośrodku [18].

Neutrony są rejestrowane przez układ detekcyjny pozwalający wykryć neutrony termiczne, nadtermiczne i rejestrować kwanty gamma oddzielnie ze zdarzeń elastycznych i z wychwytu radiacyjnego. Czas spowolnienia neutronów jest zależny od ilości wodoru występującego w skale. Głównym jego źródłem w skałach jest woda wypełniająca pory oraz szczeliny, dlatego za pomocą wskazań sond neutronowych można powiązać jej obecność z porowatością ośrodka skalnego [18].

Profilowania jądrowe są przede wszystkim wykorzystywane do pozyskania informacji o porowatości badanej skały oraz o jej składzie litologicznym.

Współczynnik porowatości jest wyznaczany w oparciu o profilowania gamma-gamma gęstościowe PGGg (Density Log). Dzięki zjawisku rozpraszania Comptonowskiego możliwe jest wyznaczanie gęstości objętościowej ośrodka skalnego.

Bezpośrednim mierzonym parametrem jest gęstość elektronowa formacji - zbliżona do gęstości objętościowej. Współczynnik porowatości można obliczyć z następującego wzoru [5]:

$$
\Phi_{D}=\frac{p_{m a}-p_{b}}{p_{m a}-p_{f}}
$$

gdzie:

$\Phi_{D}-$ współczynnik porowatości z profilowań PGGg [-], $p_{m a}-$ gęstość składników szkieletu skalnego $\left[\mathrm{g} / \mathrm{cm}^{3}\right]$, $p_{f}$ - gęstość płynów w przestrzeni porowej $\left[\mathrm{g} / \mathrm{cm}^{3}\right]$, $p_{b}-$ gęstość objętościowa $\left[\mathrm{g} / \mathrm{cm}^{3}\right]$.

Współczynnik porowatości jest również wyznaczany z profilowań neutronowych: mierzona jest obecność wodoru w formacji skalnej, który występuje przede wszystkim w wodzie zawartej w przestrzeni porowej. Zasięg pomiaru jest niewielki, rzędu $30 \mathrm{~cm}$, co odpowiada strefie przemytej. Jeśli szkielet skalny nie zawiera atomów wodoru i jest znany indeks HI cieczy, wtedy współczynnik porowatości z metody neutronowej $\Phi_{N}[-]$ odpowiada porowatości całkowitej. Indeks HI wody oraz ropy jest podobny, dlatego $\Phi_{N}$ przy obecności ropy w przestrzeni porowej nie zmienia się. Gaz ziemny posiada natomiast znacznie niższy indeks HI, wartość $\Phi_{N}$ jest wtedy niższa i zaniżana jest porowatość całkowita.

Współczynnik porowatości efektywnej można w przybliżeniu wyznaczyć za pomocą średniej arytmetycznej $\Phi_{N} \mathrm{i} \Phi_{D}[4]$ :

$$
\Phi_{e f f} \cong \frac{1}{2}\left(\Phi_{N}+\Phi_{D}\right)
$$

gdzie:

$\Phi_{\text {eff }}$ - współczynnik porowatości efektywnej [-],

$\Phi_{N}$ - współczynnik porowatości z profilowania neutronowego [-],

$\Phi_{D}$ - współczynnik porowatości z profilowania gamma-gamma gęstościowego [-].

Uzyskanie dokładniejszych wyników wymaga zastosowania techniki wykresu krzyżowego (crossplot) gęstościowo-neutronowego. Wykresy krzyżowe obrazują zróżnicowane reakcje profilowań geofizycznych na litologię, porowatość oraz zawartość mediów złożowych. Wykresy krzyżowe PGG i PNN są jednymi z najczęściej stosowanych przy rozpoznawaniu porowatości oraz składu mineralnego skał.

Analizy litologiczne wykonywane w oparciu o profilowania jądrowe mają na celu wyznaczenie rozkładu objętościowego minerałów i mediów złożowych w ośrodku skalnym. Do tego celu wykorzystuje się opisane powyżej profilowania promieniotwórczości naturalnej lub spektrometryczne profilowania neutron - gamma sPNG (profilowania geochemiczne).

Profilowania geochemiczne są szczególnie istotne z punktu widzenia udostępniania gazu ze złóż niekonwencjonalnych, ponieważ pozwalają na dokładne scharakteryzowanie mineralogiczne skał łupkowych. Rejestrowana jest zawartość poszczególnych pierwiastków w skale. W przypadku poszukiwań węglowodorów najważniejszymi z nich są węgiel i tlen. Obliczenie stosunku C/O pozwala na bezpośredni pomiar węglowodorów [18]. Dodatkowo możliwy jest pomiar zawartości krzemu, wapnia, żelaza i siarki w badanej 
skale. Po przetworzeniu uzyskanych danych otrzymuje się procent wagowy głównych grup minerałów: ilastych (WCLA), kwarcu, skaleni i mik (WQFM), węglanów (WCAR) oraz pirytu (WPYR).

Otrzymane wyniki zestawia się drogą profilowań geochemicznych z rezultatami pomiarów laboratoryjnych rdzeni wiertniczych, które uzyskuje się głównie w oparciu o metodę dyfrakcji rentgenowskiej (XRD). Otrzymuje się dane odpowiadające wynikom profilowań geochemicznych: procent wagowy iłu całkowitego (CLA), kwarcu całkowitego, skaleni i mik (QFM) oraz węglanów całkowitych (CAR) [2].

Dla uzupełnienia danych stosuje się mikroprofilowania oporności dostarczające informacji o warstwach skalnych zbyt małych, by mogły być wykryte przez sondę do profilowania geochemicznego.

Otworowe profilowania jądrowe w procesie projektowania zabiegów hydraulicznego szczelinowania są wykorzystywane do uzyskiwania informacji litologicznych, które przekładają się w szczególności na skład płynów zabiegowych.
Płyny te muszą spełniać szereg zadań: powodować otwarcie i rozrost szczeliny, zapewniać dobre właściwości transportowe podsadzki, mieć niskie opory przepływu i być kompatybilne ze złożem. W skałach łupkowych o dużej zawartości minerałów ilastych stosuje się płyny zawierające środki kontroli pęcznienia, mikroemulsje i nanoemulsje.

Profilowania geochemiczne są dodatkowo dobrym uzupełnieniem profilowań akustycznych, dzięki dostarczaniu informacji o zawartości poszczególnych minerałów w skale. Przy projektowaniu zabiegów szczelinowania szczególnie ważna jest zawartość krzemionki, która bezpośrednio wpływa na parametry mechaniczne skały. Wraz ze wzrostem zawartości krzemionki w skale, zwiększa się jej wytrzymałość. Duża zawartość krzemionki sugeruje więc wysokie wartości modułu Younga i niskie współczynnika Poissona. Jeżeli informacje te zostaną potwierdzone profilowaniami akustycznymi, można przyjąć, że skała taka będzie podatna na hydrauliczne szczelinowanie, a ciśnienie szczelinowania dla niej będzie wysokie.

\section{Profilowania magnetyzmu jądrowego}

Metody magnetyczne NMR (Nuclear Magnetic Resonance) są wykorzystywane do badania skał, których atomy posiadają moment pędu (spin) oraz wewnętrzny moment magnetyczny. Jądra atomów wodoru mają ładunki elektryczne, które przez ruch wirowy wytwarzają pola magnetyczne, reprezentowane przez momenty magnetyczne będące bez obecności zewnętrznego pola magnetycznego w stanie nieuporządkowanym. W cewce nadawczej sondy wytwarzane jest pole magnetyczne około 100 razy silniejsze od pola ziemskiego, które - oddziałując na atomy wodoru - powoduje ustawienie ich momentów magnetycznych równolegle do linii generowanego pola. Po odjęciu zewnętrznego pola momenty magnetyczne dokonują swobodnej precesji oraz powracają do stanu pierwotnego po czasie zwanym czasem relaksacji. Mierzonym parametrem jest współczynnik porowatości dynamicznej (wskaźnik FFI - wskaźnik cieczy swobodnej) oraz czasy relaksacji $T_{1}$ i $T_{2}[8,19]$.
Profilowania magnetyzmu jądrowego używane są od lat 80. XX wieku do badania porowatości efektywnej skał i nasycenia wodą oraz węglowodorami $[8,12]$. Porowatość mierzona tą metodą zależy przede wszystkim od ruchomych mediów złożowych i mimo że jej wyznaczenie jest stosunkowo skomplikowane, metoda ta ma niepodważalne zalety. Po pierwsze powiązanie z płynami złożowymi powoduje, że porowatość NMR jest bardzo zbliżona do porowatości efektywnej. Po drugie NMR pozwala na bardzo precyzyjne wyznaczenie porowatości w skałach o dużej zawartości substancji ilastej (np. łupkach gazonośnych), w których wyznaczenie porowatości inną metodą może być utrudnione [5].

Zestawienie wyników z profilowań porowatości, metodami elektrometryczną i NRM, pozwala na prawidłowy dobór wydajności tłoczenia, rodzaju płynu zabiegowego oraz podsadzki (patrz: Profilowania elektrometryczne).

\section{Profilowania akustyczne}

W metodach akustycznych wykorzystuje się właściwości fal sprężystych rozchodzących się w ośrodku skalnym. Stosuje się sondy wyposażone w nadajniki magnetostrykcyjne, emitujące impulsy fal w paśmie akustycznym. Fala rozchodzi się w płuczce wypełniającej odwiert, a następnie na granicy odwiert-ośrodek skalny ulega zjawiskom odbicia oraz załamania. Sygnał jest następnie rejestrowany: najpierw przez odbiornik umieszczony bliżej nadajnika (w czasie $T_{1}$ ), a następnie przez odbiornik bardziej odległy, o ile sonda taki posiada $\left(T_{2}=T_{1}+\Delta T\right)$ (rysunek 2). Czas $\Delta T$ jest nazywany czasem interwałowym i w przypadku cylindrycznego otworu o gładkich ściankach odzwierciedla on rzeczywisty czas przebiegu fali w ośrodku skalnym [1].

Dzięki metodzie akustycznej można wyznaczyć współczynnik porowatości i współczynnik przepuszczalności. Tłumienie fali w ośrodkach porowatych zależy przede wszystkim 


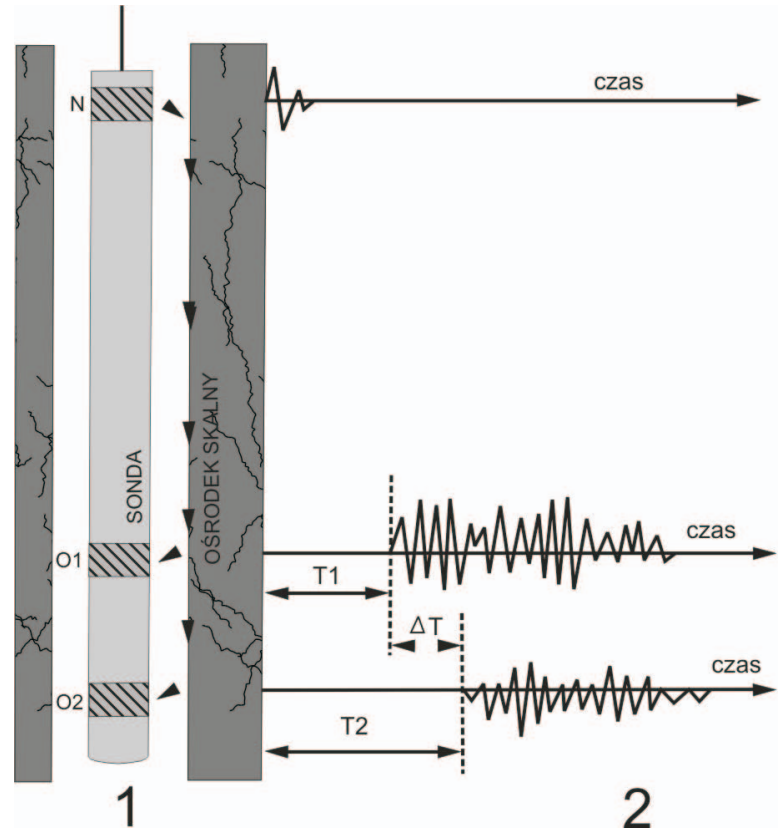

Rys. 2. Profilowanie akustyczne: 1 - schemat przebiegu fali podłużnej, 2 - uproszczony zapis obrazów falowych [1]

od obecności płynów w porach. Jeśli znane są właściwości sprężyste ośrodka (szkieletu skalnego i mediów porowych), na podstawie czasów propagacji fali sprężystej w szkielecie skalnym i w mediach wypełniających, można wyznaczyć współczynnik porowatości [5]:

$$
\Phi_{s}=A \frac{\Delta t-\Delta t_{m a}}{\Delta t_{f}-\Delta t_{m a}}
$$

gdzie:

$\Phi_{s}$ - współczynnik porowatości z profilowań akustycznych [-], $A$ - stała,

$\Delta t$ - czas interwałowy propagacji fali akustycznej w for$\operatorname{macji}[\mu \mathrm{s} / \mathrm{m}]$,

$\Delta t_{m a}$ - czas interwałowy propagacji fali akustycznej w szkielecie skalnym $[\mu \mathrm{s} / \mathrm{m}]$,

$\Delta t_{f}$ - czas interwałowy propagacji fali akustycznej w mediach wypełniających przestrzeń porową $[\mu \mathrm{m} / \mathrm{s}]$.

Ponieważ zasięg profilowań akustycznych jest niewielki (około $30 \mathrm{~cm}$ w strefie przemytej), przyjmuje się, że właściwości mediów wypełniających przestrzeń porową mogą być w przybliżeniu określone jako właściwości płuczki.

Współczynnik przepuszczalności można wyznaczyć, wykorzystując właściwości fali powierzchniowej Stonleya, rozchodzącej się pomiędzy dwoma ośrodkami sprężystymi [5]. Wraz ze wzrostem przepuszczalności prędkość fali Stonleya maleje oraz zwiększa się jej tłumienie.

Pomiary akustyczne pozwalają również wyznaczyć parametry mechaniczne skał. Dokonuje się tego w oparciu o metodę pomiaru akustycznego obrazu falowego, polegającą na rejestracji kilku rodzajów fal w określonym oknie czasowym. Rejestrowanymi falami w pierwszej kolejności są fale P o niskich amplitudach. Następnie w ośrodkach o dobrych właściwościach sprężystych rejestrowane są fale $\mathrm{S}$, przemienne, charakteryzujące się znacznie wyższymi amplitudami (występują przy założeniu, że prędkość fali w ośrodku skalnym jest większa od prędkości fali w płuczce). Fale $\mathrm{S}$ w płuczce biegną jako fale podłużne i zmieniają się w poprzeczne na granicy ośrodka. Rejestrowane są także inne typy fal związane z granicą płuczka-ośrodek skalny: fale pseudo-Reighleya, Stonleya oraz fale wielokrotnie odbite od ścianek otworu i fale dyfrakcyjne [1]. Pomiarów dokonuje się przy pomocy sond akustycznych wyposażonych w nadajniki monopolowe oraz dipolowe, emitujące fale akustyczne o zróżnicowanych częstotliwościach. Profilowania wykonywane przy użyciu tego rodzaju sond nazywane są często profilowaniami Cross-Dipole.

Dzięki badaniom czasu propagacji poszczególnych typów fal można wyznaczyć dynamiczne parametry mechaniczne skał [5].

$$
\begin{gathered}
G=\rho_{b} \frac{d^{2}}{\Delta t_{s}^{2}} \\
v=\frac{\frac{1}{2}\left(\frac{\Delta t_{s}}{\Delta t_{P}}\right)^{2}-1}{\left(\frac{\Delta t_{s}}{\Delta t_{P}}\right)^{2}-1}
\end{gathered}
$$

gdzie:

$G$ - moduł ścinania [Pa],

$d$ - stała odległość między nadajnikiem a odbiornikiem,

$v$ - współczynnik Poissona [-],

$p_{b}$ - gęstość objętościowa $\left[\mathrm{g} / \mathrm{cm}^{3}\right]$,

$\Delta t_{s}-$ różnica czasów dojścia fali $\mathrm{S}[\mu \mathrm{s} / \mathrm{m}]$,

$\Delta t_{p}-$ różnica czasów dojścia fali $\mathrm{P}[\mu \mathrm{s} / \mathrm{m}]$.

Współczynnik Poissona $v$ jest stosunkiem rozszerzenia poprzecznego do skrócenia podłużnego skały pod wpływem przyłożonych naprężeń i zależy od głębokości zalegania skał, składu mineralogicznego itp.

Skała, która deformuje się pod wpływem naprężenia tak samo poziomo i podłużnie, posiada współczynnik Poissona $v=0,5$. Materiał, który nie deformuje się poziomo pod wpływem podłużnego obciążenia, ma współczynnik Poissona $v=0[12]$.

W procesie szczelinowania współczynnik Poissona ściśle związany jest z ciśnieniem potrzebnym do utworzenia szczeliny (ciśnienie szczelinowania) oraz ciśnieniem, w którym szczelina zamyka się, pozostając podsadzona (ciśnienie zamknięcia szczeliny). Wraz ze wzrostem wartości współczynnika 
Poissona rośnie ciśnienie szczelinowania oraz ciśnienie zamknięcia szczeliny (rysunek 3). Oznacza to, że najbardziej podatne na szczelinowanie są skały o niskich wartościach współczynnika Poissona.

Modułu Younga $E[\mathrm{~Pa}]$ jest powiązany z modułem ścinania i współczynnikiem Poissona w następujący sposób [5]:

$$
E=2 G(1+v)
$$

Moduł Younga może być interpretowany jako pomierzona „sztywność” skały, czyli zdolność do utrzymania szczeliny pod wpływem nacisku. Zależy on od jej struktury: im bardziej jest ona drobnoziarnista, tym współczynnik $E$ jest większy. Podobny wpływ ma uwarstwienie skały. Moduł Younga służy do obliczania rozwartości szczeliny oraz energii potrzebnej do jej utworzenia. Wraz ze wzrostem modułu Younga rośnie ciśnienie szczelinowania (rysunek 4), powiększa się długość szczeliny oraz maleje jej rozwartość (rysunek 5). Innymi słowy, najbardziej podatne na szczelinowanie są skały charakteryzujące się wysokimi wartościami modułu Younga.

Wyznaczenie modułu Younga i współczynnika Poissona jest niezbędne między innymi do prawidłowego dobrania płynu szczelinującego wykorzystywanego w zabiegu oraz wydajności jego tłoczenia. W formacjach miękkich o dużej plastyczności, charakteryzujących się niskim modułem Younga i wysokim współczynnikiem Poissona stosuje się płyny o dużej lepkości (sieciowane). W formacjach kruchych posiadających wysokie wartości modułu Younga i niskie wartości współczynnika Poissona używa się płynów o niskiej lepkości (Slickwater) [3, 4, 10]. Łupki gazonośne są skałami kruchymi, dlatego też do ich szczelinowania stosuje się przeważnie ciecze o niskich lepkościach, typu Slickwater. W związku z tym, że skały te są również bardzo słabo przepuszczalne, konieczne jest wytworzenie szczelin i mikroszczelin łączących szczeliny naturalne. Zatłacza się przez to znacznie większe ilości płynu zabiegowego i materiału podsadzkowego.

Przypływ gazu ze złoża do odwiertu przez wytworzone w zabiegu szczeliny jest uwarunkowany odpowiednim ich podparciem, do czego służą materiały podsadzkowe (Proppants). W kruchych formacjach łupkowych nawet szczelina niewypełniona podsadzką może być efektywna w transporcie gazu [9]. Istnieje kilka rodzajów podsadzek używanych podczas szczelinowania płynami typu Slickwater. Charakteryzują się one niskim ciężarem właściwym oraz wysoką odpornością na naprężenia ściskające. Ziarna podsadzki o gęstości zbliżonej do gęstości wody mogą być łatwiej transportowane w dalsze części szczeliny. Podsadzki charakteryzujące się porowatością otwierają dodatkowe kanały dla przepływu gazu w szczelinie $[9,11,15]$.

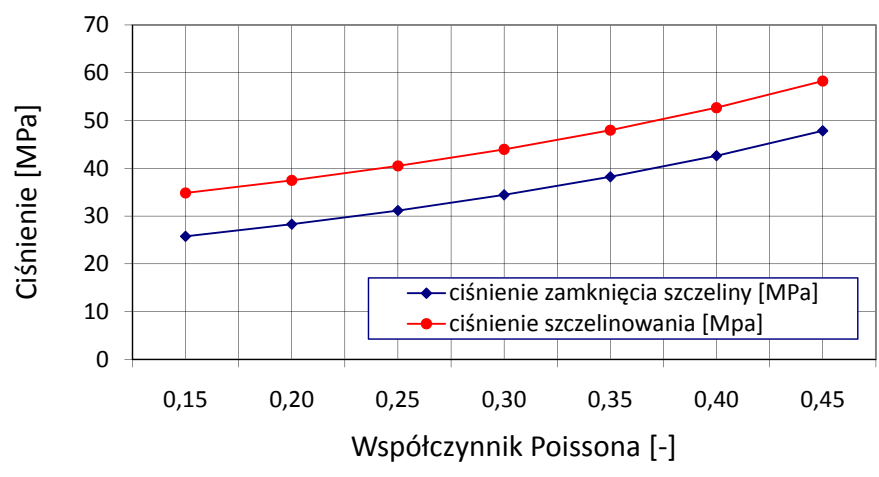

Rys. 3. Wpływ współczynnika Poissona na parametry hydraulicznego szczelinowania

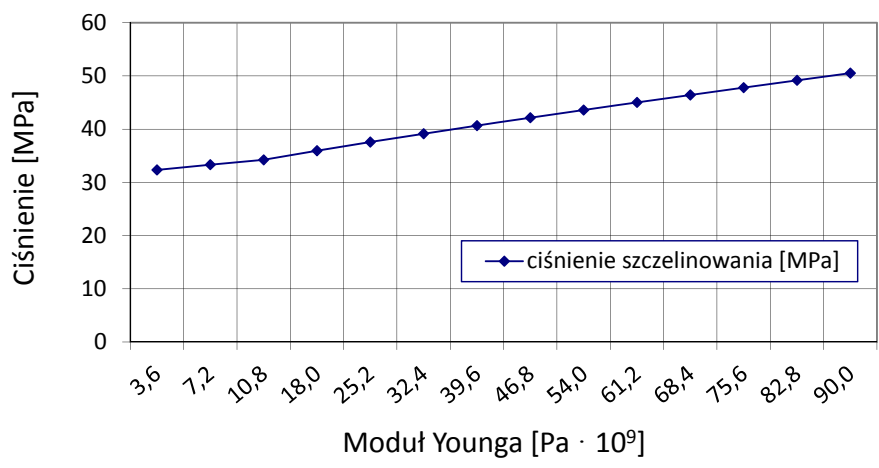

Rys. 4. Wpływ modułu Younga na parametry hydraulicznego szczelinowania

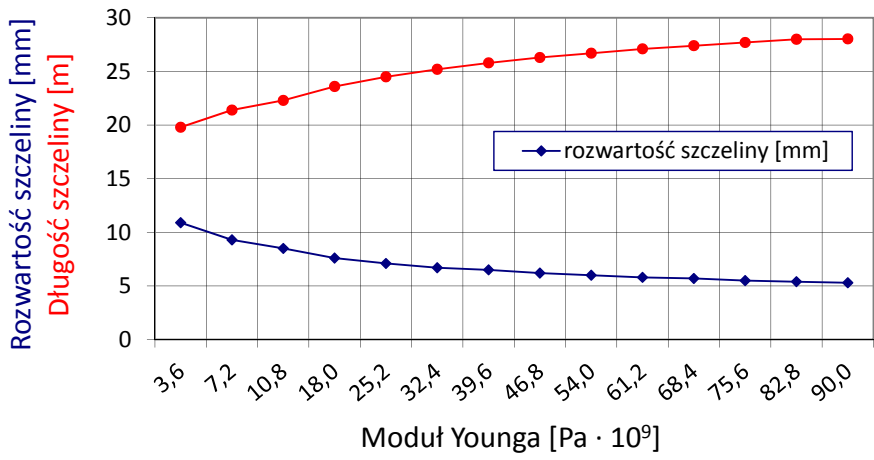

Rys. 5. Wpływ modułu Younga na parametry hydraulicznego szczelinowania

Profilowania akustyczne pozwalają również na wyznaczenie rozkładu naprężeń w złożu. Podczas zabiegu hydraulicznego szczelinowania tworzą się szczeliny propagujące w kierunku prostopadłym do kierunku minimalnych naprężeń. Kiedy minimalnymi naprężeniami są naprężenia pionowe związane ze skałami nadkładu (0-1000 m), może się wytworzyć szczelina pozioma. Natomiast, gdy minimalnymi naprężeniami są naprężenia poziome (>1000 m), może powstać także szczelina pionowa. W przypadku polskich złóż łupkowych, ze względu na głębokość ich zalegania (poniżej $2500 \mathrm{~m}$ ), minimalnymi naprężeniami będą naprężenia poziome, a więc w złożach tych powstaną szczeliny pionowe [3]. 
Znajomość kierunku i wartości naprężeń w złożu oraz w bezpośredniej jego okolicy jest kluczowym elementem podczas projektowania zabiegu szczelinowania, ponieważ wpływa ona bezpośrednio na wartości takie jak ciśnienie szczelinowania i ciśnienie zamknięcia szczeliny. Ważna jest również znajomość profilu różnicy naprężeń pomiędzy poszczególnymi warstwami w sąsiedztwie skały złożowej. Różnica ta wpływa bezpośrednio na wysokość szczeliny (propagację w kierunku wertykalnym). Wraz ze wzrostem tej różnicy zwiększa się szansa, że szczelina wytworzona podczas

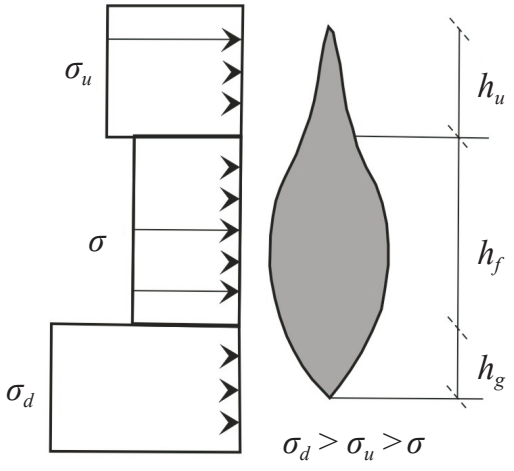

Rys. 6. Zależność pionowej propagacji szczeliny od występujących naprężeń zabiegu obejmie swoim zasięgiem jedynie warstwę złożową i nie przeniknie do warstw sąsiadujących.

W przypadku, gdy występujące w złożu naprężenia $(\sigma)$ są najmniejsze, w serii stropowej nieco większe $\left(\sigma_{u}\right)$, a największe w spągu $\left(\sigma_{d}\right)$, szczelina ma kształt wydłużony w kierunku pionowym w górę i przebija się przez formację złożową (rysunek 6). W sytuacji, kiedy naprężenia w stropie i spągu złoża są równe $\left(\sigma_{d}=\sigma_{u}\right)$ i znacznie większe od występujących w złożu $(\sigma)$, pionowa wysokość szczeliny jest równa miąższości złoża (rysunek 7).

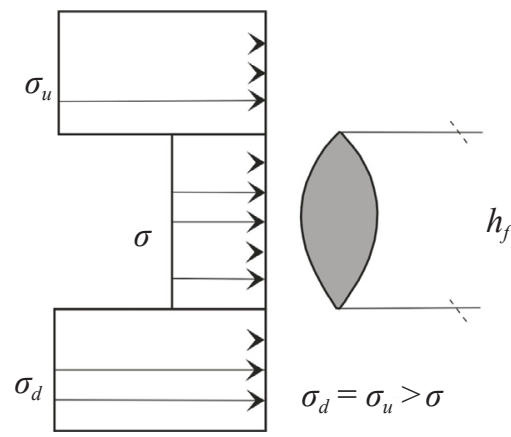

Rys. 7. Zależność pionowej propagacji szczeliny od występujących naprężeń

\section{Podsumowanie}

Do zaprojektowania i przygotowania zabiegu hydraulicznego szczelinowania niezbędna jest znajomość szeregu parametrów geologicznych charakteryzujących formację skalną, takich jak: skład litologiczny i mineralogiczny, współczynniki porowatości i przepuszczalności, nasycenie wodą oraz węglowodorami oraz znajomość własności mechanicznych ośrodka i rozkładu naprężeń w złożu.

Jednym z podstawowych źródeł informacji na temat powyższych parametrów są profilowania geofizyki otworowej: elektrometryczne, jądrowe, nuklearnego rezonansu magnetycznego oraz akustyczne. Każde z nich dostarcza informacji o parametrach geologicznych w odmienny, właściwy dla siebie sposób, jednak jednocześnie uzyskiwane wyniki wzajemnie się przenikają i uzupełniają, finalnie dając czytelny obraz badanej strefy złożowej.

Znajomość litologii, właściwości mechanicznych badanej skały, danych modułem Younga i współczynnikiem
Poissona, oraz rozkładu naprężeń w ośrodku umożliwia zaprojektowanie optymalnej geometrii szczeliny, a także oszacowanie kierunku propagacji szczeliny w skale.

Współczynniki porowatości, przepuszczalności, nasycenie oraz skład mineralogiczny pozwalają wyznaczyć parametry zabiegowe: ciśnienie tłoczenia, wydajność tłoczenia, ilość zatłaczanej cieczy, jej rodzaj oraz zawartość dodatków specjalnych, takich jak środki kontroli pęcznienia czy antyemulgatory. Umożliwiają one również dobranie odpowiedniego rodzaju podsadzki, określenie jej optymalnej frakcji i ilości.

Nie należy jednak zapominać, że wyniki profilowań geofizyki otworowej muszą być uzupełniane wynikami z analiz laboratoryjnych i dopiero wówczas, po połączeniu informacji z obydwu metod, możliwe jest uzyskanie pełnego i kompletnego obrazu geologicznego analizowanego obszaru złożowego.

Prosimy cytować jako: Nafta-Gaz 2016, nr 1, s. 23-32, DOI: 10.18668/NG2016.01.03

Artykuł nadesłano do Redakcji 17.03.2015 r. Zatwierdzono do druku 23.05.2015 r.

Artykuł powstał na podstawie pracy własnej pt. Wykorzystanie metod geofizyki otworowej w projektowaniu i przygotowaniu technologii zabiegów hydraulicznego szczelinowania - finansowanej przez INiG - PIB, nr zlecenia: 1848/KS/2014. 


\section{Literatura}

[1] Bala M.: Profilowania akustyczne [w:] Jarzyna J., Bala M., Zorski T.: Metody geofizyki otworowej. Wydawnictwa Akademii Górniczo-Hutniczej, Kraków 1997, s. 87-105.

[2] Cameron-Diaz H., Miller C., Lewis R.: sCore: A Mineralogy Based Classification Scheme for Organic Mudstones. Conference Materials: SPE Annual Technical Conference and Exhibition held in New Orleans, Louisiana, USA, 30 September - 2 October 2013, SPE 166284.

[3] Ciechanowska M., Matyasik I., Such P., Kasza P., Lubaś J.: Uwarunkowania rozwoju wydobycia gazu z polskich formacji tupkowych. Nafta-Gaz 2013, nr 1, s. 7-17.

[4] Czupski M., Kasza P., Wilk K.: Płyny do szczelinowania złóż niekonwencjonalnych. Nafta-Gaz 2013, nr 1, s. 42-50.

[5] Desroches J., Bratton T.: Formation Characterization: Well Logs [w:] Economides J., Nolte K.: Reservoir Stimulation. Third Edition. Houston, Texas 2000, s. 4.1-4.24.

[6] Ellis D., Singer J.: Well Logging for Earth Scientists. 2nd Edition. Springer 2008, s. 2-15, 260-264.

[7] Jarzyna J.: Profilowania elektrometrii otworowej [w:] Jarzyna J., Bala M., Zorski T.: Metody geofizyki otworowej. Wydawnictwa Akademii Górniczo-Hutniczej, Kraków 1997, s. 28-70.

[8] Jarzyna J.: Profilowania magnetyczne [w:] Jarzyna J., Bala M., Zorski T.: Metody geofizyki otworowej. Wydawnictwa Akademii Górniczo-Hutniczej, Kraków 1997, s. 168-180.

[9] Kasza P.: Efektywne szczelinowanie tupków w Polsce. Nafta-Gaz 2013, nr 11, s. 807-813.

[10] Kasza P.: Zabiegi hydraulicznego szczelinowania $w$ formacjach tupkowych. Nafta-Gaz 2011, nr 12, s. 874-883.

[11] Kasza P.: Zabiegi stymulacji wydobycia w niekonwencjonalnych złożach węglowodorów. Nafta-Gaz 2011, nr 10 , s. 697-701.

[12] Kasza P., Czupski M., Biały E.: Nowe technologie stymulacji wydobycia ropy naftowej i gazu ziemnego. Materiały szkoleniowe Instytutu Nafty i Gazu - Państwowego Instytutu Badawczego, 2006.

[13] Kielt M.: Geofizyka wiertnicza w poszukiwaniu złóż węglowodorów. Tom I. Wydawnictwo Adam Marszałek, Torun 2002, s. 44-73.
[14] King G.: Thirty Years of Gas Shale Fracturing: What Have We Learned? Conference materials: SPE Annual Technical Conference and Exhibition held in Florence, Italy 19-22 September 2010, SPE 133456

[15] Market J., Quirein J., Wicher J., Hinz D., Buller D., Al.-Dammad C., Spain D., Odumosu T.: Logging-WhileDrilling in Unconventional Shales. Conference materials: SPE Annual Technical Conference and Exhibition held in Florence, Italy 19-22 September 2010, SPE 133685.

[16] Masłowski M.: Materiały podsadzkowe do zabiegów hydraulicznego szczelinowania złóż niekonwencjonalnych. Nafta-Gaz 2014, nr 2, s. 75-83.

[17] Poprawa P.: System weglowodorowy z gazem ziemnym w lup kach - pólnocnoamerykańskie doświadczenia i europejskie perspektywy. Przeglad Geologiczny 2010, tom 58, s. 216-225.

[18] Smith M. B., Shlyapobersky J. W.: Basic of Hydraulic Fracturing [w:] Economides J., Nolte K.: Reservoir Stimulation. Third Edition. Houston, Texas 2000, s. 5.1-5.27.

[19] Zorski T.: Profilowania jadrowe. [w:] Jarzyna J., Bala M., Zorski T.: Metody geofizyki otworowej. Wydawnictwa Akademii Górniczo-Hutniczej, Kraków 1997, s. 106-162.

[20] Zorski T., Jarzyna J., Derkowski A., Srodon J.: Geofizyka otworowa $w$ dobie poszukiwań gazu w lupkach - przeglad metod pomiarowych. Przegląd Geologiczny 2013, tom 61, s. $424-434$

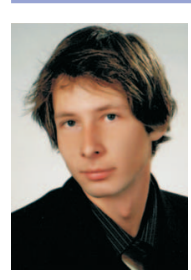

Mgr Rafał MOSKA

Specjalista inżynieryjno-techniczny w Zakładzie Stymulacji Wydobycia Węglowodorów. Instytut Nafty i Gazu - Państwowy Instytut Badawczy ul. Lubicz 25 A

31-503 Kraków

E-mail: rafal.moska@inig.p 